\author{
KatARZyNa Winiecka \\ UNIWERSYTET W BIAŁYMSTOKU \\ E-MAIL: KATARZYNA.WINIECKA@GMAIL.COM
}

\title{
POTRZEBA EDUKACJI MIĘDZYKULTUROWEJ W SPOŁECZNOŚCIACH LOKALNYCH NA PRZYKŁADZIE BADANIA PARTYCYPACJI W KULTURZE I POTRZEB KULTURALNYCH MIESZKAŃCÓW SEJN
}

\section{Wprowadzenie}

Istotne znaczenie w życiu współczesnych społeczeństw odgrywają ruchy ludności. Owe procesy prowokują do zróżnicowanych dyskusji w tym obszarze. Jednym $z$ takich tematów, szeroko podejmowanym przez nauki humanistyczne i społeczne jest wielo- i międzykulturowość. Kiedy dochodzi do kontaktów przedstawicieli odmiennych kulturowo, wcześniej niezaznajomionych ze sobą grup, zauważa się zjawiska, które mogą być niepokojące dla ogółu społeczeństwa. Jest to między innymi rodzenie się antagonizmów międzygrupowych, czy też postaw ksenofobicznych. Te trudności w integracji powinny otwierać pole do działań z zakresu edukacji międzykulturowej. Wydaje się, że w warunkach „nowych” kontaktów międzykulturowych działania w tym zakresie są naturalnym i właściwym posunięciem, aczkolwiek niekoniecznie postrzeganym jako pożądane przez wszystkich aktorów życia społecznego. Odnieść można wrażenie, że w aktualnym dyskursie publicznym prowokowanym ostatnim napływem migrantów do Europy, edukację międzykulturową kojarzy się najczęściej z sytuacjami, w których należy uczyć się siebie nawzajem - od początku. Należy kreować pewną jakość kontaktów społecznych opartych na nowej konfiguracji ról i statusów społecznych. Działania takie stanowią wyzwanie i są jednocześnie tylko fragmentem obszaru zainteresowań edukacji międzykulturowej. 
Jeśli przyjrzymy się historii życia człowieka na Ziemi, to można z powodzeniem stwierdzić, że wielokulturowość istniała niemal od zawsze. W konsekwencji ruchów ludnościowych, uwarunkowań geopolitycznych uformowało się wiele społeczności, które w swojej strukturze posiadają przedstawicieli różnych kultur, grup narodowościowych i etnicznych. W rzeczywistości funkcjonują grupy zróżnicowane kulturowo, które w swojej formie, podziale ról, organizacji życia codziennego są ukonstytuowane od dawna. Potocznie mówiąc - każdy zna swoje miejsce. Czy jest to od razu równoznaczne z pozytywną koegzystencją, wzajemnym poszanowaniem norm i wartości kulturowych lub dobrą wzajemną znajomością? Czy grupy odmienne kulturowo, ale zaliczające się do tej samej społeczności stale muszą się edukować? Jaka jest więc rola edukacji międzykulturowej w takich przypadkach? Czy w społecznościach od lat zróżnicowanych kulturowo istnieje w ogóle taka potrzeba?

Celem artykułu jest próba odpowiedzi na powyższe pytania. Empirycznej podstawy do tego dostarczają wyniki badania „Zasoby i potrzeby kulturalne mieszkańców Sejn" [Winiecka, Miszkiel 2015] przeprowadzonego w 2015 roku w ramach projektu ${ }^{1}$ Narodowego Centrum Kultury - „Dom Kultury + Inicjatywy Lokalne 2015”. Badanie nie było ukierunkowane na diagnozę potrzeb związanych z edukacją międzykulturową, ale przeprowadzane analizy ukazały wątki, które są bezpośrednio związane z tą tematyką. Casus Sejn jest o tyle interesujący, że to jedna z nielicznych miejscowości w kraju, w której ponad 10\% mieszkańców deklaruje inną narodowość niż polską, w tym przypadku litewską ${ }^{2}$. Na tle podobnych miejscowości w Polsce, odznacza się wysoką aktywnością kulturalną w zakresie zbliżenia różnych kultur. Biorąc pod uwagę fakt, że społeczeństwo polskie jest wyraźnie homogeniczne ${ }^{3}$, kwestia edukacji międzykulturowej w małych społecz-

1 Badanie zostało zrealizowane w ramach Programu Narodowego Centrum Kultury „Dom Kultury + Inicjatywy lokalne 2015”. Program został przygotowany w ramach współpracy ministra kultury i dziedzictwa narodowego oraz Narodowego Centrum Kultury z ekspertami i przedstawicielami Obywateli Kultury. Zakłada on współpracę z przedstawicielami społeczności lokalnej. Główny nacisk położony jest na nawiązywanie przez domy kultury stałych relacji z mieszkańcami. http://www.nck. pl/strona-glowna/277633-oglaszamy-nabor-wnioskow-do-programu-dom-kultury-inicjatywy-lokalne-2015/ [10.11.2015] Podstawą do wdrożenia głównych założeń projektu była diagnoza i ewaluacja działalności Ośrodka Kultury oraz zasobów i potrzeb kulturalnych mieszkańców Sejn. (http:// www.nck.pl/dom-kultury-plus, [10.11.2016].

2 (http://stat.gov.pl/cps/rde/xbcr/gus/Przynaleznosc_narodowo-etniczna_w_2011_NSP.pdf, [12.11.2016].

3 Polska jest jednym z najbardziej jednolitych narodowościowo i etnicznie krajów w całej Unii Europejskiej. Jeśli weźmie się dodatkowo pod uwagę takie kraje, jak Norwegia, Islandia, Lichtenstein i Szwajcaria, to Polska jest najbardziej homogenicznym krajem niemal w całej Europie. Badania Eu- 
nościach lokalnych, o względnie trwałych i niemal niezmiennej strukturze staje się ciekawym przedmiotem analiz.

Podstawowymi kategoriami pojęciowymi, jakimi posługuję się w artykule jest pojęcie „wielokulturowości” i „edukacji międzykulturowej”. Rozumienie obydwu pojęć przyjmuję za Jerzym Nikitorowiczem [2015]. Wielokulturowość definiuję więc, jako „współwystępowanie na tej samej przestrzeni grup o odmiennych kulturowych cechach; (...) zjawisko tożsamościowe, ideologiczne i edukacyjne" [Nikitorowicz 2015: 28]. W poruszanym kontekście szczególnie zwraca uwagę aspekt edukacyjny, ponieważ występowanie wielokulturowości na danym obszarze, w danej społeczności, czy społeczeństwie implikuje pewne działania edukacyjne. Natomiast edukację międzykulturową traktuję jako: „ogół wzajemnych wpływów i oddziaływań jednostek i grup, instytucji, organizacji, stowarzyszeń, związków sprzyjających takiemu rozwojowi człowieka, aby stawał się on w pełni świadomym i twórczym członkiem wspólnoty (...) oraz był zdolny do aktywnej samorealizacji, kształtowania trwałej tożsamości i odrębności” [Nikitorowicz 2009: 282].

\section{Edukacja międzykulturowa}

Współczesne społeczeństwa europejskie w swoim nastawieniu do wielokulturowości charakteryzują się dwoma podejściami. Z jednej strony widoczne jest dążenie do zacierania granic kulturowych, do tworzenia zunifikowanej społeczności obywatelskiej, czy globalnej wspólnoty ludzkiej. Z drugiej zaś do dywersyfikacji życia kulturowego [Chodubowski 2013: 36]. Marek Szopski [2005] zwraca uwagę, że bez względu na podejście do wielokulturowości, kultura dla ludzi jest czymś niezmiernie istotnym. Nie tylko pozwala na identyfikację i określenie własnej przynależności, ale także wyznacza tory postępowania, a w konsekwencji daje poczucie bezpieczeństwa [Szopski 2005: 5]. Poczucie bezpieczeństwa wydaje się być kluczową kwestią. Z jednej strony wiemy, kim jesteśmy, wiemy, do jakich norm i wartości możemy się odwoływać, opierając się na nich kreujemy swój wzorzec postępowania. Z drugiej zaś poczucie „kulturowego bezpieczeństwa” może być zagwarantowane przez poznanie innych kultur, z którymi człowiek

rostatu wskazują, że tylko $0,1 \%$ obywateli Polski jest innej narodowości niż polska. Jest to najniższy odsetek wszystkich krajów wchodzących w skład Unii Europejskiej. (http://ec.europa.eu/eurostat/ statistics-explained/index.php/File:Total_population_and_resident_non-national_population_by_ group_of_citizenship,_2011.png, [15.11.2016]. 
obcuje na co dzień. Wzajemna wymiana doświadczeń, czy zdobywanie wiedzy może zbudować relacje wyzbyte postaw ksenofobicznych, uprzedzeń, czy nieprawdziwych stereotypów. W środowiskach zróżnicowanych kulturowo taki stan rzeczy wydaje się wręcz pożądany. Można tu przywołać chociażby słowa Tadeusza Lewowickiego [2015]. Autor zwraca uwagę, że edukacja międzykulturowa powinna ukazywać Innych i ich kulturę pozostałym członkom społeczeństwa w celu zbliżenia się, upowszechniania uniwersalnych wartości, wzbogacania kultur poprzez oferowanie własnego dorobku i jednoczesną możność czerpania z dorobku innych [Lewowicki 2014: 28].W kontekście omawianego zagadnienia - potrzeb edukacji międzykulturowej w społecznościach lokalnych - warto podkreślić powiązania pomiędzy edukacją międzykulturową a wielokulturowością. Lewowicki jest zdania, że edukacja międzykulturowa powinna traktować wielokulturowość jako zróżnicowanie narodowościowe, etniczne, rasowe, ale co więcej, jako zróżnicowanie kulturowe ludzi, którzy przynależą do jednej społeczności i grup etnicznych narodowościowych, środowiskowych i wielu innych. Autor dodaje, że w takich warunkach zróżnicowanie kulturowe występuje wszędzie i dotyczy rozmaitych sfer życia [Lewowicki 2014: 28]. Także w małych, zastanych społecznościach, które wzorce postępowania i hierarchie mają ukonstytuowane od lat. W sytuacji, kiedy nawet szersze społeczeństwo posiada charakter niemal stricte homogeniczny, występowanie na niewielkim obszarze grup zróżnicowanych kulturowo i tworzących jedną społeczność stanowi obszar oddziaływań dla edukacji międzykulturowej. „(...) Ważne przy tym jest poszukiwanie tych wartości, które są wspólne i akceptowane, pożyteczne ze społecznego punktu widzenia. Dostrzegane są różnice i kształtowane zrozumienie i szacunek do innych kultur" [Lewowicki 2014: 28].

Gdy pojawia się potrzeba edukacji międzykulturowej istotną kategorią pojęciową jest „zmiana”. Jak dostrzega Andrzej Radziewicz-Winnicki [1995] na zmianę społeczną składają się procesy, które między innymi umożliwiają wejście na kolejny poziom rozwoju. Owe zmiany mogą objawiać się w zachowaniach jednostkowych dotyczących między innymi postaw. Mogą nie mieć większego wpływu na funkcjonowanie społeczności, ale też mogą mieć charakter trwały, niemal strukturalny. Będą to radykalne zmiany rzutujące na codzienne życie jednostek i grup społecznych. W kontekście społeczności zróżnicowanych kulturowo (i nie tylko) istotny staje się wektor zmian. Ktoś lub coś musi zarządzać zmianą, aby nie przyjęła niewła- 
ściwego kierunku. Tu objawia się rola edukacji międzykulturowej. Poprzez edukację międzykulturową kreowana jest nowa jakość funkcjonowania społeczeństwa uwzględniająca różnorodność kulturową, z zachowaniem bezpieczeństwa wszystkich aktorów. Kształtowana jest też odpowiednia dynamika zmian, która powinna gwarantować pewien bufor bezpieczeństwa pomiędzy uczestniczącymi w tym procesie grupami. Jest to proces ciągłego stawania się społeczeństwem, kształtowania się wspólnoty funkcjonującej na zasadach wzajemnej tolerancji i wzajemnego poszanowania.

W przypadku Europy „próby edukacyjnych działań podyktowanych wielokulturowością pojawiły się na szerszą skalę wraz z upowszechnianiem oświaty elementarnej w wielonarodowych monarchiach w XIX wieku i na początku wieku XX" [Lewowicki 2014: 20]. Pomimo tego, że Polskę mniejszości narodowe i grupy etniczne zamieszkiwały od lat, edukacja międzykulturowa długo nie była obecna. Działania w tym zakresie hamowały rozbiory, później kolejne zawirowania polityczne. W okresie przedwojennym „ponad 30\% mieszkańców Polski było przedstawicielami innych narodowości, dziś jest ich znacznie mniej. Po I i II wojnie światowej, akcjach wysiedleńczych oraz usilnych dyskryminacyjnych działaniach władz PRL, Polska stała się niemal jednolita kulturowo" [Mościka 2015: 28]. Dopiero po 1989 roku i zmianie ustrojowej mniejszości narodowe i etniczne żyjące na terenie Polski zaczęly na powrót zaznaczać swoją obecność. Polityka społeczna Polski zaczęła uwzględniać obecność grup odmiennych kulturowo i promować ideę społeczeństwa wielokulturowego oraz namawiać grupy mniejszościowe (narodowe, etniczne i religijnie) do promowania swojej kultury, a tym samym inności [por. Mościka 2015: 30]. Aczkolwiek „wielokulturowość" Polski po upadku komunizmu nie dorównywała stanowi z okresu przedwojennego. Wieloletnie forsowanie polityki kraju jednolitego kulturowo przyczyniło się do zmian świadomościowych skutkujących długim niedostrzeganiem Innych w społeczeństwie polskim. Zrodziły się antagonizmy, bądź stale podtrzymywano te, które istniały od lat. W konsekwencji (czego przykładem będą poniżej prezentowane badania) wciąż istnieje potrzeba edukacji międzykulturowej w społecznościach lokalnych, które od lat w swoich szeregach mają przedstawicieli różnych kultur i narodów.

4 Według Spisu Powszechnego z 2011 roku 3,8\% respondentów deklarowało, że jest innej narodowości niż polska. 


\section{Sejny jako obszar badawczy - założenia metodologiczne}

Zanim przejdę do prezentacji metodologii zastosowanej $\mathrm{w}$ badaniu, zwrócę uwagę na Sejny jako obszar badań. Jest to miasto powiatowe położone w północno-wschodniej części województwa podlaskiego, nieopodal granicy z Litwą. Współczesny charakter Sejn jest uwarunkowany przez wielokulturowe dziedzictwo. Miasto na przestrzeni wieków zamieszkiwali Polacy, Żydzi, Rosjanie, Niemcy i inne narodowości oraz grupy etniczne Obecnie największą mniejszością narodową zamieszkującą Sejny są Litwini ${ }^{5}$. Według ostatniego Spisu Powszechnego Sejny zamieszkiwało 5709 osób, a w 2014 roku 5640 osób ${ }^{6}$.

„Sejny są miejscowością, w której funkcjonują liczne ośrodki, instytucje oraz fundacje i stowarzyszenia podejmujące działalność kulturalną. Do głównych zaliczają się: Ośrodek Kultury, Dom Litewski, Ośrodek «Pogranicze-sztuk, kultur, narodów», Biblioteka Publiczna, Muzeum Ziemi Sejneńskiej. Funkcjonuje też Sejneńskie Towarzystwo Opieki nad Zabytkami, Litewskie Towarzystwo św. Kazimierza, Stowarzyszenie Społeczne na rzecz Rozwoju, Oświaty, Kultury i Sportu, (...) czy Uniwersytet Trzeciego Wieku (...). Do zwiedzania jest udostępniony Klasztor Podominikański, w którym mieści się Muzeum Diecezji Sejneńskiej” [Winiecka, Miszkiel 2015]. Wydawane są też dwie gazety i funkcjonuje kilka sejneńskich portali internetowych. Widać, że jak na niespełna sześciotysięczną miejscowość działa wiele instytucji, które odpowiadają, bądź mogłyby odpowiadać za edukację międzykulturową w mieście.

Głównym celem badania była diagnoza zasobów kulturalnych Sejn oraz potrzeb mieszkańców na obszarze kultury. Z wyżej postawionego celu wynikło szereg celów szczegółowych, między innymi:

- określenie sposobu i poziomu uczestnictwa w kulturze mieszkańców Sejn,

- analiza preferencji i potrzeb kulturalnych mieszkańców miasta,

- określenie determinantów uczestnictwa w wydarzeniach kulturalnych,

- zdiagnozowanie znajomości poszczególnych instytucji i atrakcyjności dostępnej oferty kulturalnej w Sejnach.

5 http://www.muzeum.sejny.pl/s/w-krotkim-zarysie, [20.11.2016].

6 http://stat.gov.pl/bdl, [07.11.2016]. Statystyczne Vademecum Samorządowca, Gmina Miejska Sejny. Powiat Sejneński. Urząd Statystyczny, Białystok 2015. 
W badaniu zastosowano podejście jakościowo-ilościowe, w tym technikę indywidualnego wywiadu pogłębionego (IDI) i wywiadu kwestionariuszowego (PAPI). W przypadku badań ilościowych uczestniczyło 356 respondentów, a dobór próby miał charakter kwotowy. Zmiennymi branymi pod uwagę były wiek i płeć. Ustalono następujące kohorty wiekowe: 15-19 lat, 20-24 lata, 25- 29 lat, 30-34 lata, 35-39 lat, 40-44 lata, 45-49 lat, 50-54 lata, 55-59 lat, 60-64 lata, 65-69 lat, 70 lat i powyżej. Do stworzenia struktury prób wykorzystano dane pochodzące z Banku Danych Lokalnych GUS. Natomiast w badaniu jakościowym wzięły udział trzy osoby. Wywiady pogłębione zrealizowano z pracownikami kultury, z dwoma mężczyznami i jedną kobietą. W przeciwieństwie do badań ilościowych w tym przypadku zmienne takie, jak wiek i płeć nie miały dużego znaczenia. Bardziej liczyło się doświadczenie zawodowe respondentów, co brano pod uwagę przy doborze specjalistów do wywiadu pogłębionego. Osoby badane były ekspertami w dziedzinie kultury. Posiadały wiedzę praktyczną i teoretyczną, między innymi na temat zarządzania instytucjami kultury, organizacji przedsięwzięć kulturalnych, współpracy międzyinstytucjonalnej, jak i ogólnie życia kulturalnego w Sejnach. Były reprezentantami sektorów publicznego i pozarządowego [zob. Winiecka, Miszkiel 2015]. Badanie zostało zrealizowane na przełomie kwietnia i maja 2015 roku.

Generalnie badanie miało na celu diagnozę potrzeb i zasobów kulturalnych mieszkańców Sejn. Niemniej ujawniło ono wątki, które odnoszą się do potrzeb związanych z edukacją międzykulturową.

\section{Potrzeba edukacji międzykulturowej na przykładzie miasta Sejny - wyniki badań}

Sejneńska społeczność, co już zostało podkreślone, jest wyjątkowa na tle Polski ponieważ w jej skład wchodzą grupy o różnej kulturze i odmiennym dziedzictwie kulturowym. Można powiedzieć, że w związku z dość zawiłą historią miasta w konsekwencji rozpoczęły działalność instytucje kulturalne (Dom Litewski, Ośrodek Pogranicze Sztuk - Kultur - Narodów, Muzeum Sejneńskie i inne), które miałyby podtrzymać, czy kultywować wielokulturowy charakter społeczności i tożsamość miasta. Wydawałoby się, że wielowieczna, wspólna i wielokulturowa historia miasta doprowadziła do takiego status quo, które nie pozostawia miejsca na działalność w obszarze edukacji międzykulturowej. Badanie natomiast uchwyciło nieco inny obraz rzeczywistości społecznej. 
W jakościowej części badania ekspertów pytano między innymi o występowanie współpracy międzyinstytucjonalnej, której owocem byłyby działania skierowane do całej społeczności Sejn.

Jeden $\mathrm{z}$ respondentów uznał, że nie ma żadnych barier we współpracy, ale jednocześnie nie ma wspólnych działań programowych. Natomiast dwaj pozostali praktycznie jednogłośnie przyznali, że istnieją bariery mentalno-historyczne pomiędzy Polakami i Litwinami, które determinują kształt współpracy, bądź jej brak. Ich zdaniem cały czas bardzo duże znaczenie mają zaszłości historyczne, urazy, jakie żywią w stosunku do siebie przedstawiciele obu grup narodowościowych. Ich zdaniem stale jest widoczny podział na „swoich” i „obcych”. Co z jednej strony jest naturalne, chociażby w kontekście podtrzymywania własnej identyfikacji narodowej, ale z drugiej strony może przyjmować formę antagonizmów. Co ciekawe, badani możliwość współpracy widzą na dwóch poziomach: międzyinstytucjonalnym i ogólnospołecznym. Bariery we współpracy na poziomie instytucjonalnym przejawiają się w braku wspólnych działań programowych między ośrodkami kultury. Bariery funkcjonują też na poziomie mieszkańców miasta, którzy ze względu przynależności do danej narodowości nie angażują się w działania wybranych ośrodków reprezentujących odmienną narodowość niż własną.

Rozmówcy stwierdzają:

„Mamy tę różnorodność i trzeba to podkreślić. Mamy mniejszości i nie można tak zrobić że Litwini robią swoje święta dla siebie, a Polacy dla siebie... ale to tak wygląda na dzień dzisiejszy. Jest ten podział, ale trzeba przenikać z grupy do grupy. Jednak to są bariery mentalne. Mam taką niechlubną tradycję. (...)Młode pokolenie może tego już nie pamięta, ale rodzice, dziadkowie mają te swoje żale. To się przelewa... przesiąka cały czas". (R2)

„Są bariery litewsko-polskie, polsko-litewskie. Przeszkadza trudne dziedzictwo - mentalne, historyczne. Dostaje się naklejkę, że idziesz za mocno tutaj, albo tutaj. (...) Ale szukamy tego co łączy”. (R3)

Badani eksperci zwrócili uwagę, że współpracy na polu międzykulturowym nie sprzyja małomiasteczkowy charakter Sejn. W opinii interlokutorów niewielka liczba mieszkańców rodzi obawę przed oceną innych. Jak stwierdza jeden $\mathrm{z}$ respondentów: „nie podejmuje się pewnych aktywności wykraczający poza konkretny obszar działalności kulturalnej przypisanej pewnej narodowości”. (R2)

Zatem można przypuszczać, że w mniejszych miejscowościach brakuje pewnego rodzaju „bezpiecznej anonimowości”, która nie utożsamiałaby 
działań instytucjonalnych z prywatnymi poglądami działacza, czy animatora kultury. Ale tak naprawdę, czy w funkcjonowaniu społeczności zróżnicowanej kulturowo chodzi o anonimowość, która de facto pozwala na ukrycie przynależności do pewnej grupy bądź identyfikacji z nią? Tutaj widzimy nie tylko ograniczenia, które mogą odbijać się na funkcjonowaniu konkretnej osoby, ale także na kształtowaniu się działalności konkretnych instytucji, które w związku $\mathrm{z}$ takim podejściem mogą nadal być ukierunkowane w swoich działaniach na wybraną grupę narodowościową zamiast na całą społeczność. Ponadto, zaburzone jest formowanie się wielokulturowej wspólnotowości.

Jednocześnie w wywiadach cały czas wybrzmiewało, że zróżnicowanie narodowościowe Sejn jest wielkim atutem i generalnie istnieje duża potrzeba współpracy pomiędzy środowiskiem polskim i litewskim.

„Wszyscy w Sejnach się orientują co nas odróżnia od innych podobnych miast, i co jest takim walorem. (...) To jest wielokulturowość tego miejsca. To, że historycznie małe Sejny były zbudowane przez różnego pochodzenia etnicznego ludzi, używających na co dzień kompletnie różniących się języków, chodzących do innych świątyń itd. Dzisiaj Sejny to miasteczko głownie polsko-litewskie, ale to jest walor, który stanowi o pewnej wyjątkowości tego miejsca. (...) Wielokulturowość wykorzystuje się w działaniach. (...) Litwini mają własne instytucje i nie tylko instytucje edukacyjne, ale i kultury. Oni mają bardzo dobrze rozbudowaną infrastrukturę. Każda mniejszość jest skupiona na tym, żeby utrzymać swoją tożsamość, a aby to zrobić w pewnym stopniu trzeba być zamkniętym na świat zewnętrz. I to jest wyzwanie! To nie jest bariera to jest wyzwanie! Trzeba tak zbudować program, aby był atrakcyjny dla wszystkich!”. (R1)

Dostrzeżono potrzebę wspólnych działań jednocześnie podkreślając, że brakuje osoby, która mogłaby łączyć środowiska i koordynować działania. Występuje brak lidera społecznego działającego na polu kontaktów międzykulturowych. Chociaż przy ocenie poszczególnych ośrodków kultury najlepiej został oceniony Ośrodek Pogranicze sztuk - kultur - narodów, który jest najbardziej zaangażowany w dialog międzykulturowy.

Rozmówcy określili też "podziały” narodowościowe występujące na terenie Sejn jako czynnik ogólnie hamujący partycypację w kulturze. „Wskazano na następujące aspekty tego zagadnienia: język jako bariera «techniczna» - ograniczona oferta ośrodków litewskich w języku polskim; historyczne uwarunkowania, częściowo stawiające dwie społeczności w opozycji oraz wpływające na postrzeganie uczestnictwa we wzajemnych wydarzeniach jako źle widzianą aktywność, oraz brak lidera łączącego obie grupy. Podkreślano, że wszystkie z wyżej wymienionych barier nie stosują 
się do każdej kategorii społecznej w poszczególnych grupach narodowościowych. Przykładowo większy opór we wzajemnych, polsko-litewskich i litewsko-polskich relacjach posiadają starsze pokolenia mieszkańców" (Winiecka, Misztal 2015).

Choć powyżej przedstawione dane nie mają charakteru reprezentatywnego, są jednak ważnym „głosem” w dyskusji na temat potrzeby edukacji międzykulturowej w społecznościach, które od lat są zróżnicowane kulturowo.

Z kolei badanie ilościowe dostarczyło danych na temat konkretnych potrzeb mieszkańców Sejn w obszarze kultury i zasobów kulturalnych dostępnych w mieście. Cześć badania była poświęcona znajomości i partycypacji w poszczególnych instytucjach. Respondentom zadano pytanie, które z pięciu podstawowych instytucji funkcjonujących w mieście znają chociażby ze słyszenia. Do badania wybrano takie instytucje jak: Muzeum Ziemi Sejneńskiej, Ośrodek - Pogranicze - sztuk, kultur, narodów, Dom Litewski,Ośrodek Kultury oraz Bibliotekę Publiczną. Pierwsze trzy są instytucjami, które zdecydowanie ukazują zróżnicowany kulturowo charakter miasta.

Nie jest zaskoczeniem, że $\mathrm{w}$ tak ogólnym pytaniu badani deklarowali wysoką znajomość poszczególnych placówek (tabela 1). Sejny są małą miejscowością i generalnie działalność instytucji jest znana. Ponad 94\% badanych deklarowało, że zna Muzeum Ziemi Sejneńskiej i tyle samo Ośrodek Kultury. Nieco mniej wskazań dotyczyło Ośrodka Pogranicze - sztuk, kultur, narodów i Domu Litewskiego. Przy podziale na płeć i wiek nie zauważono istotnych różnic statystycznych.

Tabela 1. Znajomość instytucji kultury w Sejnach (w \%)

\begin{tabular}{|l|c|}
\hline Muzeum Ziemi Sejneńskiej & 94,9 \\
\hline Ośrodek Kultury & 94,6 \\
\hline Biblioteka Publiczna & 91,8 \\
\hline Ośrodek Pogranicze sztuk, kultur, narodów & 88,5 \\
\hline Dom Litewski & 87,3 \\
\hline
\end{tabular}

Źródło: Badania własne, PAPI, Pytanie wielokrotnej odpowiedzi [Winiecka, Miszkiel 2015]. 
Jednak znajomość „ze słyszenia” nie odzwierciedla poziomu partycypacji. Kolejna tabela (Tabela 2.) przedstawia uczestnictwo w poszczególnych instytucjach w ciągu ostatnich 12 miesięcy.

W tym przypadku należy zwrócić uwagę na wariant odpowiedzi „nie byłem/am”. Instytucje, które przybliżają wielokulturowy charakter Sejn, czyli na przykład Ośrodek „Pogranicze - sztuk - kultur - narodów” nigdy nie został odwiedzony przez ponad połowę mieszkańców $(52,1 \%)$. Podobnie sytuacja wygląda w przypadku Domu Litewskiego. Tam nigdy nie było 51,4\% sejneńczyków. W przypadku Muzeum Ziemi Sejneńskiej jest to nieco powyżej $1 / 3$ mieszkańców $(36,4 \%)$. Biorąc pod uwagę częstotliwość odwiedzin w poszczególnych ośrodkach to zauważa się, że im większa częstotliwość odwiedzin tym niższy odsetek osób deklarujących wizyty w poszczególnych placówkach.

Tabela 2. Częstotliwość wizyt w instytucjach kultury w Sejnach w ciągu ostatnich 12 miesięcy (dla całej próby w \%)

\begin{tabular}{|l|c|c|c|c|c|}
\hline Wyszczególnienie & $\begin{array}{c}\text { Muzeum } \\
\text { Ziemi } \\
\text { Sejneńskiej }\end{array}$ & $\begin{array}{c}\text { Ośrodek } \\
\text { Kultury }\end{array}$ & $\begin{array}{c}\text { Ośrodek } \\
\text { Pogranicze } \\
\text { sztuk, kultur, } \\
\text { narodów }\end{array}$ & $\begin{array}{c}\text { Dom } \\
\text { Litewski }\end{array}$ & $\begin{array}{c}\text { Biblioteka } \\
\text { Publiczna }\end{array}$ \\
\hline Nie byłem\am & 36,4 & 18,8 & 52,1 & 51,4 & 25,4 \\
\hline Raz w roku & 32,2 & 32,4 & 24,1 & 21,8 & 26,2 \\
\hline Raz na pół roku & 16,9 & 26,1 & 9,9 & 11,6 & 16,3 \\
\hline $\begin{array}{l}\text { Raz na kilka } \\
\text { miesięcy }\end{array}$ & 10,7 & 18,2 & 8,2 & 11,9 & 13,8 \\
\hline Raz w miesiącu & 2,0 & 2,0 & 3,4 & 2,3 & 10,7 \\
\hline $\begin{array}{l}\text { Raz w tygodniu } \\
\text { i Częściej }\end{array}$ & 1,7 & 2,6 & 2,3 & 1,1 & 7,6 \\
\hline
\end{tabular}

Źródło: Badania własne, PAPI [Winiecka, Miszkiel 2015].

Analiza najczęściej wykonywanych w wolnym czasie czynności w ostatnich 12 miesiącach przez mieszkańców Sejn wydaje się potwierdzać powyższe dane (tabela 3). Wśród dziesięciu najczęściej wykonywanych czynności nie znalazła się ani jedna aktywność, która miałaby związek z jakąkolwiek działalnością instytucji działającej na polu edukacji lub dialogu międzykulturowego. Deklaracje uczestnictwa w działaniach domów kultury, ośrod- 
ków kulturalnych, czy korzystanie z takich miejsc jak biblioteka uplasowały się na dalszych pozycjach.

Tabela 3. Czynności wykonywane w ciągu ostatnich 12 miesięcy

\begin{tabular}{|l|c|}
\hline Wyszczególnienie & Procent \\
\hline Spacerowanie & 93,4 \\
\hline Wizyta w domu u znajomych & 89,7 \\
\hline Oglądanie telewizji & 86,6 \\
\hline Wizyta na grillu & 82,1 \\
\hline Uprawianie sportu & 75,2 \\
\hline Wizyta w galerii handlowej & 74,6 \\
\hline Wizyta na bezpłatnym festynie lub koncercie plenerowym & 74,4 \\
\hline $\begin{array}{l}\text { Oglądanie filmów na Video, DVD, komputerze, słuchanie } \\
\text { muzyki }\end{array}$ & 72,9 \\
\hline Przeczytanie książki dla przyjemności & 67,5 \\
\hline Wizyta w restauracji & 66,4 \\
\hline
\end{tabular}

Źródło: Badania własne, PAPI [Winiecka, Miszkiel 2015].

Wyniki badań można odnieść do zagadnienia edukacji międzykulturowej, ale też do uczestnictwa w kulturze w ogóle. Można postawić tezę, że generalnie ludzie potrzebują edukacji w zakresie partycypacji w kulturze [zob. Poleszczuk i in., 2012]. Bez świadomości, że uczestnictwo w kulturze w ogóle jest ważne, droga do działań mających na celu wzajemne przybliżanie odmiennych kultur będzie trudna. Na liście dziesięciu najczęściej wykonywanych czynności w czasie wolnym wśród mieszkańców Sejn, niewiele ma związek z rzeczywistą partycypacją w kulturze.

Powyżej prezentowane dane sygnalizują, że choć wielokulturowa historia miasta może być długa, to wymaga stałej pracy nad wspólnymi relacjami, które mogłyby wciąż przybliżać i jednocześnie podtrzymywać charakter i specyfikę poszczególnych społeczności. 


\section{Zakończenie}

Starając się odpowiedzieć na postawione we wprowadzeniu pytania należy zaznaczyć, że grupy zróżnicowane kulturowo, żyjące w granicach jednej społeczności wypracowały znany wszystkim aktorom model koegzystencji. Znajomość reguł, jakie panują w danej społeczności rodzi poczucie funkcjonowania pewnej umowy społecznej, która pozwala żyjącym tam grupom odgrywać swoje role i zajmować określone pozycje. Natomiast nie jest to równoznaczne ze stwierdzeniem faktu, że wszyscy się godzą z zajmowanymi w hierarchii społecznej pozycjami. Obserwacja, która wyłoniła się z badań, a mianowicie brak „pośrednika” pomiędzy zróżnicowanymi kulturowo grupami, przy jednoczesnej możliwości realizacji własnych planów i celów, może świadczyć, że owa koegzystencja istnieje, ale jej charakter wcale nie musi być już tak bardzo oczywisty. W dążeniu do wspólnotowości, do wypracowania wspólnych sposobów działania, dzielenia się wiedzą, wzajemnego czerpania $\mathrm{z}$ własnego dziedzictwa ważna jest kooperacja. Ta wymaga obustronnego poznania, a przede wszystkim interakcji. W tym przypadku wydaje się, że edukacja międzykulturowa w takich typach społeczności jest niezbędna z kilku powodów. Wielokulturowe dziedzictwo powinno stać się podstawą do kreowania wspólnej tożsamości grup zróżnicowanych kulturowo, jak chociażby mieszkańców jednego miasta. Ucząc się wzajemnie o swoich kulturach ludzie poznają własną kulturę, a tym samym budują własną tożsamość. Wymiana informacji, wspólne działania są też podstawą do kreowania społeczeństwa obywatelskiego, które może decydować o samostanowieniu. Podziały na „my” i „oni” zawsze będą obecne. Niemniej w ramach jednej społeczności edukacja międzykulturowa może poprawić komfort i jakość życia mieszkańców jako wspólnoty wielokulturowej.

\section{Bibliografia}

Chodubski A. (2013), Mniejszości narodowe i etniczne a współczesne przemiany europejskie, [w:] 25 lat funkcjonowania mniejszości narodowych, etnicznych i regionalnych $w$ demokratycznej Polsce, red. E. Subocz, Olsztyn.

Lewowicki T. (2014), Edukacja międzykulturowa. Od lokalnych sukcesów ku globalnym przesłaniom i oddziaływaniom, „Edukacja Międzykulturowa”, nr 3. 
Mościcka D.M., (2015), Współczesna polska wielokulturowość, „Kwartalnik Szkice Humanistyczne", t. 38, nr 3-4.

Nikitorowicz J. (2009), Edukacja regionalna i międzykulturowa, Warszawa.

Nikitorowicz J. (2015), Ku jakim strategiom w edukacji międzykulturowej $w$ kontekście współczesnych problemów wielokulturowościowych?, „Pogranicze. Studia Społeczne”, t. XXV.

Poleszczuk J. i in. (2012), Diagnoza partycypacji w kulturze w województwie podlaskim, Białystok.

Radziewicz-Winnicki A. (1995), Modernizowanie niedostrzegalnych obszarów rodzimej edukacji, Katowice.

Szopski M. (2005), Komunikowanie międzykulturowe, Warszawa.

Statystyczne Vademecum Samorzadowca, Gmina Miejska Sejny. Powiat Sejneński, (2015), Białystok, Urząd Statystyczny (dostępny pdf: http://bialystok.stat.gov.pl/vademecum/ vademecum_podlaskie/portrety_gmin/powiat_sejnenski/gmina_miejska_sejny.pdf).

Winiecka K., Misztal B., (2015) Zasoby i potrzeby kulturalne mieszkańców Sejn. Raport z badań, Sejny.

\section{Strony internetowe}

http://ec.europa.eu/eurostat/statisticsexplained, [15.11.2016].

http://www.nck.pl/dom-kultury-plus, 10.11.2016].

https://bdl.stat.gov.pl/BDL/start, [12.11.2016].

http://stat.gov.pl, [12.11.2016].

http://www.um.sejny.pl/sejny_w_skrocie, [20.11.2016].

http://www.muzeum.sejny.pl, [20.11.2016].

http://bialystok.stat.gov.pl, [20.11.2016].

http://pogranicze.sejny.pl, [24.11.2016]. 


\section{SUMMARY}

\section{The need of intercultural education in the local societies.Based on research of participation in culture and cultural needs of Seiny inhabitants}

The main goal of the article is indication the need of intercultural education in a local society. In the paper is discussed an example of Sejny - the small city in north-east part of Poland. Despite of long, common history of two different social groups, living in the same city - Poles and Lithuanians - there is a need of collaboration on the field of intercultural education. The discussion is based on the theoretical considerations and research which was conducted in 2015 in Sejny within the project of National Center of Culture - „Dom Kultury + Inicjatywy Lokalne 2015.

KEYWORDS: culture, education, intercultural education, local society 